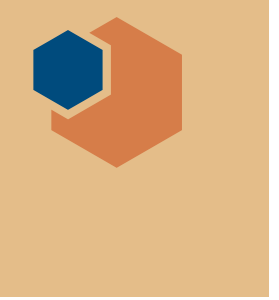

\section{Advanced manufacturing emphasized in US FY2016 budget request}

\author{
www.whitehouse.gov/ostp
}

$\mathrm{I}_{\mathrm{P}}^{\mathrm{n}}$ this year's State of the Union address, President Barack Obama identified examples of research and development (R\&D) that directly involve materials research, "I want Americans to win the race for the kinds of discoveries that unleash new jobs - converting sunlight into liquid fuel; creating revolutionary prosthetics...." He said, "Twenty-first century businesses will rely on American science and technology, research and development."

He backed his statements, the following month, with his budget request that includes \$146 billion for R\&D overall, an $\$ 8$ billion or 6\% increase from 2015 enacted levels.

Yet, in terms of the budget for materials R\&D, Nabil Bassim — who chairs the Government Affairs Committee (GAC) of the Materials Research Society (MRS) - defines the funding climate as flat. "It hasn't been great in the last few years," he says.

However, particularly exciting in this year's proposal for the materials research community is the administration's emphasis on advanced manufacturing. "The President focuses on manufacturing, which is reflected in the NIST [National Institute of Standards and Technology] budget request," says Damon Dozier, Director of Government Affairs at MRS. NIST's budget request includes \$150 million to coordinate the National Network for Manufacturing Innovation across multiple federal departments and agencies and to fund two institutes for five years. Most importantly, the budget proposes a $\$ 1.93$
Table: Fiscal Year 2016 Budget Request (In millions of US dollars)

\begin{tabular}{|c|c|c|}
\hline & $\begin{array}{l}\text { Request } \\
\text { FY } 2016\end{array}$ & $\begin{array}{l}\text { Variance from } \\
2015 \text { Actuals (\%) }\end{array}$ \\
\hline \multicolumn{3}{|l|}{ Department of Defense } \\
\hline Army Science and Technology Programs & $\$ 12266.6$ & -13.9 \\
\hline Navy Programs & $\$ 2155.3$ & -1.9 \\
\hline Air Force Programs & $\$ 2378.4$ & +4.2 \\
\hline DARPA & $\$ 2972.7$ & +6.1 \\
\hline \multicolumn{3}{|l|}{ Department of Energy } \\
\hline Office of Energy Efficiency and Renewable Energy & $\$ 2720$ & +42.3 \\
\hline $\begin{array}{l}\text { Materials Sciences and Engineering Division } \\
\text { (in Office of Science) }\end{array}$ & $\$ 375.3$ & +3 \\
\hline ARPA-E & $\$ 325$ & +16 \\
\hline \multicolumn{3}{|l|}{ National Science Foundation } \\
\hline Mathematical and Physical Sciences Directorate (MPS) & $\$ 1336$ & +2.2 \\
\hline Division of Materials Research (in MPS) & $\$ 315.8$ & +2.9 \\
\hline $\begin{array}{l}\text { Cyber-Enabled Materials, Manufacturing, } \\
\text { and Smart Systems }\end{array}$ & $\$ 257$ & +13 \\
\hline \multicolumn{3}{|l|}{ National Institute of Standards and Technology } \\
\hline Scientific and Technical Research and Services & $\$ 754.7$ & +11.7 \\
\hline National Network for Manufacturing Innovation & $\$ 150$ & +100 \\
\hline $\begin{array}{l}\text { National Institute of Biomedical Imaging } \\
\text { and Bioengineering }\end{array}$ & $\$ 337.3$ & +3.1 \\
\hline National Nanotechnology Initiative & $\$ 1540$ & 0 \\
\hline
\end{tabular}

billion one-time mandatory funding to be used in FY 2017 to FY 2024 to complete the network of up to 45 institutes, "where researchers, companies, and entrepreneurs can come together to develop new manufacturing technologies," according to the NIST budget proposal.

According to the White House, the 2016 budget proposal calls for a total of \$2.4 billion "for Federal R\&D directly supporting advanced manufacturing at [the National Science Foundation, the Department of Defense, the Department of Commerce], and other agencies, consistent with the goals and recommendations of the National Strategic Plan for Advanced Manufacturing." Among the institutes already in the network are the Institute for Advanced Composites Manufacturing Innovation (Department of Energy), Lightweight Innovations for Tomorrow (DOD), Power America (with a focus on wide-bandgap semiconductors, DOE), and America Makes (with a focus on additive manufacturing, DOD).

In other areas with a particular materials research interest, the 2016 budget proposes $\$ 12.3$ billion for the DOD Science \& Technology Program, with $\$ 3.0$ billion for the US Defense Advanced Research Projects Agency (DARPA).

The budget provides the DOE Office of Science with over $\$ 5.3$ billion and NSF with over $\$ 7.7$ billion. It also provides $\$ 755$ million for NIST laboratories. The FY 2016 proposal increases total funding for these three key basic research agencies by $\$ 0.7$ billion over the 2015 level to $\$ 13.8$ billion.

Another major initiative supported across departments and agencies is the National Nanotechnology Initiative which will hold at the same levels as last year, at \$1.54 billion.

Breaking this down into support for materials research, Dozier sees that the DOD request results in an $8.3 \%$ decrease for basic research but a $1.4 \%$ increase for applied research. Funding for DARPA, he says, would increase by $6.0 \%$ in all defense research science programs.

In the DOE Office of Science's Basic Energy Sciences (BES), funding for the Materials Science and Engineering Division will receive an increase of 3\% over FY 2015. Funding for BES, which also 
manages Scientific User Facilities and the Energy Frontier Research Centers, would increase by $6.7 \%$ over last year's numbers. A total of $\$ 325$ million is to go to the US Advanced Research Projects AgencyEnergy (ARPA-E), which supports highrisk, high-payoff materials research.

To address the administration's Materials Genome Initiative, the FY 2016 proposal requests $\$ 256.95$ million for the Cyber-Enabled Materials, Manufacturing, and Smart Systems initiative within NSF. The funding request for the Division of
Materials Research is $\$ 315.80$ million, which is an increase of $2.9 \%$ over FY 2015. Funding for 21 Materials Research Science and Engineering Centers would hold steady at \$56.0 million.

The MRS GAC has been monitoring the US R\&D budget for several years and is particularly concerned about the country's global competitiveness. According to GAC, over the past decade China has increased its R\&D expenditures by $90 \%$ and South Korea by 50\%, while US expenditures have remained relatively level.
GAC correlates this cutback in funding to the "declining rate of discovery, numbers of patents, and workforce preparedness."

The Committee on Science, Space, and Technology in the House of Representatives is also concerned with US competitiveness as the members began debating in April on how basic R\&D should be funded. Just as MRS Bulletin went to press, the Chair of the committee, Lamar Smith (R-Texas), introduced the America COMPETES Reauthorization Act of 2015 to the committee.
India urges scientists to use renewable, green material www.dst.gov.in

$\mathrm{H}$ arsh Vardhan, Union Minister for Science and Technology in India, has urged scientists and technologists working on developing low-cost building and structural material that they have got to bear most of the burden of implementing Indian Prime Minister Narendra Modi's dream of a roof above every head by 2022 .

Addressing the staff of the CSIRStructural Engineering Research Center (CSIR-SERC), a Laboratory of India's Council for Scientific and Industrial Research (CSIR), in March, Vardhan said, "Construction technologies, high science products and specialized services developed by SERC would form an essential component for the Prime Minister's project."

The Minister visited various laboratories in CSIR-SERC, which included Earthquake Engineering, Structural Health Monitoring, Wind Engineering, Structural Concrete Engineering, and Technology and Advanced Computational Structural Mechanics. He was accompanied by M.O. Garg, Director-General, CSIR, and A.B. Mandal, Director, SERC, as well as a number of industrialists. In reference to the industry representatives, Vardhan said that entrepreneurs should focus on using renewable and green materials of Indian origin, including materials based on nanotechnology that have a minimum carbon footprint and that are low cost and sustainable.

Over the past 50 years, CSIR-SERC has accumulated experience in research and development (R\&D) in the field of structural engineering covering a wide spectrum: materials for concrete, computational mechanics for analysis design of special structures, structural dynamics, earthquake engineering, wind engineering, bridge engineering, disaster mitigation, nondestructive techniques for condition assessment of concrete structures, durability of concrete structures, lightweight structures, composite construction, alternate materials, nano-engineered materials, and repair and rehabilitation of structures.

CSIR-SERC was instrumental, for example, in the areas of service life extension of concrete and steel structures of nuclear power plants, thermal power plants, and road and rail bridges, developing expertise for the systematic condition assessment using nondestructive techniques.

Now the construction industry is under pressure to increase productivity, reduce cost, and enhance the quality levels of constructed facilities. Construction in earthquake-prone areas demands lightweight, high-strength materials with large ductility or deformability for in-plane and out-of-plane loading. A prefabricated method of construction is the only solution to encounter the growing demand for housing, according to the Ministry for Science and Technology. CSIR-SERC has taken steps for meeting the demands of the housing and infrastructural facilities and to upgrade them for safe upkeep. In this context, five technologies have been developed at CSIR-SERC: prefab lightweight large panels using expanded polystyrene, pre-engineered cold-formed steel for multi-storied buildings, pre-engineered FABcrete - an innovative material for sandwich panels, self-compacting ferro-cement mortar for thin panels, and steel-foam concrete composite lightweight panels.

A large number of industrialists connected with infrastructure were present on Vardhan's visit to CSIRSERC.They included D. Adinarayana Rao (BGR Energy Systems Ltd), S.S. Mani (BHEL, Ranipet), Vivek Chari (TAG Corporation), S. Ravishankar (Adani Infra India), S. Ram Mohan (NLC, Neyveli), and D. Srinivasa Rao (Hindustan Shipyard Ltd).

\section{f $y$ materials Science POLICY}

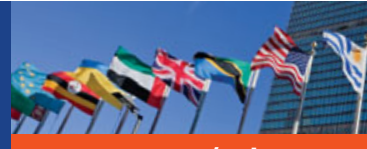

